\title{
The morphological and chemical composition characteristics of Opuntia ficus-indica and Opuntia humifusa fruits
}

\author{
Mi-Hyun Kim, Hee Jung Kim, Mi Jang, Tae-Gyu Lim, Hee-Do Hong, \\ Young Kyoung Rhee, Kyung-Tack Kim, Chang-Won Cho* \\ Traditional Food Research Center, Korea Food Research Institute, Seongnam 13539, Korea
}

\section{손바닥선인장(백년초, 천년초) 열매의 외관 및 성분특성 연구}

\author{
김미현 · 김희정 · 장미 · 임태규·홍희도 · 이영경 · 김경탁·조장원* \\ 한국식품연구원 전통식품연구센터
}

\begin{abstract}
In this study, the morphological features and the chemical composition characteristics of Opuntia ficus-indica and Opuntia humifusa fruits were investigated. The length of minor and major axis, and weight of $O$. ficus-indica and $O$. humifusa fruits were compared as the morphological features. The characteristics of components such as color, moisture, crude protein, ash, fat, dietary fiber, mineral, and amino acids were evaluated. The values of $\boldsymbol{O}$. ficus-indica fruits were higher than those of $O$. humifusa fruits in each morphological feature such as minor axis, major axis, and weight. According to the Hunter color index results, $O$. humifusa fruits showed higher values of $L$ (lightness) and $\mathbf{b}$ (yellowness), whereas $\boldsymbol{O}$. ficus-indica fruits showed higher value of a (redness). The $\Delta \mathbf{E}$ value between two samples was 19.80. The $O$. ficus-indica fruits had higher carbohydrate content and lower content of crude ash than those of $\boldsymbol{O}$. humifusa fruits. Both samples showed very high dietary fiber contents, and the major minerals were $\mathrm{K}$ and $\mathrm{Ca}$. Glutamic acid was the major amino acids in both samples. In free amino acids contents, $O$. ficus-indica had higher tyrosine and lower glutamic acid level than those of $O$. humifusa fruits. $\gamma$-aminobutyric acid was found in both samples, whereas taurine was found in $O$. ficus-indica fruits only. Taken together, the morphological features and chemical quality of $\boldsymbol{O}$. ficus-indica and $\boldsymbol{O}$. humifusa fruits showed difference although both of them were originated from the same genus.
\end{abstract}

Key words : Opuntia ficus-indica var. saboten, Opuntia humifusa, fruit, morphological feature, chemical composition

\section{서 론}

지구상에는 4,000 여종의 선인장이 있는데, 그 중 열매가 있고 줄기가 손바닥 모양처럼 생긴 부채선인장속(Opuntia) 선인장을 손바닥선인장이라 부른다(1). 우리나라에서 일반 적으로 재배되는 선인장 중 Opuntia속에 속하는 선인장은 2종으로, 제주 지역의 백년초 선인장(Opuntia ficus-indica

*Corresponding author. E-mail : cwcho@kfri.re.kr Phone : 82-31-780-9312, Fax : 82-31-709-9876

Received 8 June 2016; Revised 30 June 2016; Accepted 4 July 2016

Copyright (c) The Korean Society of Food Preservation. All rights reserved. var. saboten)과 내륙지방의 천년초 선인장(Opuntia humifusa) 으로 구분할 수 있다. 백년초는 우리나라의 제주도 등지에 서 자생 또는 재배되고 있는 귀화 식물로, 건조한 기후에서 도 잘 자라는 열대성 식물로 멕시코가 원산지이며, 높이가 약 1 2 $\mathrm{m}$ 까지 자라는 것이 특징이다(2). 반면 수 년에서 수십 년 경작이 가능한 다년생 식물인 천년초 선인장은 내륙지방에서 재배되고 있는 국내 토종 선인장으로, 열대 지방이 원산지인 백년초와 달리 영하 $20^{\circ} \mathrm{C}$ 의 혹한에서도 생존이 가능하며, 토양에서 약 $30 \mathrm{~cm}$ 정도 높이로 자란다 (3). 이전 연구결과에서 과일의 색깔, 주간과 큰 가시의 존재 여부와 같은 외부형태학적 감정 및 random amplification of polymorphic DNA(RAPD)에 의한 유전적 다양성 분석에 따른 백년초와 천년초의 유전적 동일성이 0.37로 나타나 
기원이 다른 종으로 확인되었다(1).

손바닥선인장의 가식부위는 크게 열매와 줄기로 나누어 지는데, 그 중 선인장 열매는 서양배(prickly pear)라고 명명 되며 여러 종류의 선인장에서 과실을 얻을 수 있다(4). 백년 초 열매는 매년 4 5월경에 작고 파란 열매가 열려 5 6월경 에는 열매에 꽃이 핀다. 이후 꽃이 지면서 열매가 커져 11 12월 경 열매가 익어 수확하게 된다. 붉은 천연 색소를 가지고 식이 섬유, 칼슘, 철분 등 무기질 성분이 풍부하고 핑크빛이 도는 빨간 열매의 상큼한 맛으로 널리 알려져 있다(5). 최근 백년초 열매는 잼, 쥬스 및 초콜릿 등 식품 가공 소재로 활용되고 있으며(6), 국내에서는 컵케이크(7) 및 두부(8) 등의 제조에 백년초 열매를 이용한 연구가 보고 되었다. 천년초는 6월에 꽃이 피고 7월에 꽃이 진 후 가을에 꽃이 진 자리에 열매를 맺고 10 월 경 수확한다. 천년초 열매 의 경우 짙은 붉은 색으로 맛은 매우 달고 점액질과 철분이 많은 것이 특징이다(9). 최근 천년초 열매는 생면(10), 절편 (11), 증편(12) 등의 제조에 적용되고 있다.

손바닥선인장 열매의 성분은 백년초 열매(13) 및 천년초 열매(14,15)에 대한 성분분석이 보고되어 있으나 백년초와 천년초 열매의 외관 및 성분특성을 비교한 연구는 현재 보고되어 있지 않다. 손바닥선인장의 성분은 재배지역과 같은 다양한 요소들에 의하여 다르게 나타날 수 있으며, 열매의 경우 재배지역 및 숙성정도가 성분에 영향을 미칠 수 있다. 손바닥선인장 열매의 가공을 위해서는 이러한 종 에 따른 특성들의 차이를 이해하는 것이 매우 중요한 요소 이다(16). 따라서 본 연구에서는 손바닥선인장 열매를 이용 한 식품 가공품 개발에 있어 종에 따른 열매의 특성에 대한 기초자료를 제공하고자 백년초와 천년초 열매의 외관 및 이화학적 특성을 비교 조사하였다.

\section{재료 및 방법}

\section{실험 재료}

본 실험에 사용한 백년초 열매는 제주도에 위치한 백년 초 농장에서 재배한 것을, 천년초 열매는 충남 아산지역에 위치한 천년초 농장에서 구입하여 이용하였다. 실험에 사 용된 열매 시료는 2015년 10월경에 구입하여 사용하였으 며, 외형적 특성은 각 100 개의 백년초, 천년초 열매시료를 세척, 자연건조 후 측정하였다. 외형 측정이 끝난 시료는 냉동 후 세절하고 동결건조한 후 $60 \mathrm{mesh}$ 사이즈로 균일하 게 분쇄하고 desiccator에 보관하며 성분분석을 실시하였다.

\section{외형적 특성}

백년초와 천년초 열매의 외형적 특성은 생 시료를 대상 으로 조사하였으며, 타원형인 시료의 가장 긴축을 장축 (major axis), 가장 짧은 축을 단축(minor axis)으로 정하여 $\mathrm{cm}$ 단위로 측정하였다. 열매중량의 경우 전자저울 $(\mathrm{CB}-$ 1200 , CAS, Seongnam, Korea)을 이용하여 측정하였다.

\section{색도 측정}

동결건조를 통해 얻어진 백년초와 천년초 열매 분말의 색도는 색차계(Minolta CR-200, Konica minolta Co., Tokyo, Japan)를 이용하여 측정하였다. 건조, 분쇄한 가루 형태의 시료를 무작위로 10회 반복 측정하여 L(lightness), a(chromaticity of red and green), b(chromaticity of blue and yellow)값으로 표시하였다. 색도 측정 시 표준판은 $\mathrm{L}$ 값 $97.69, \mathrm{a}$ 값 +0.37 , $\mathrm{b}$ 값 +1.96 인 백색의 calibration plate를 표준으로 하여 측정 하였다. 시료간의 색도차이를 나타내는 delta $\mathrm{E}(\mathrm{AE})$ 값은 다음의 식을 이용하여 계산하였다(17).

$$
=\left(L-L_{B}\right)+\left(a_{A}-a_{B}\right)^{2}+\left(b_{A}-b_{B}\right)^{2}
$$

(L: lightness, a: redness, b: yellowness)

\section{일반성분 함량 및 식이섬유 측정}

백년초와 천년초 열매의 성분을 측정하기 위하여 동결건 조한 후 분쇄한 분말을 사용하였다. 수분은 $105^{\circ} \mathrm{C}$ 상압가열 건조법, 조지방은 soxhlet 추출법, 조회분은 직접 회화법, 조단백의 함량은 Kjeldahl법을 이용하였다. 탄수화물은 100 에서 수분, 조단백, 조지방, 조회분 함량을 뺀 값으로 하였 다. 식이섬유 함량을 측정하기 위해 동결건조 후 분쇄한 시료를 $\mathrm{AOAC}$ 법(18)에 준하여 효소분해 하였으며, 단백질 과 회분의 함량을 함께 측정하여 총 식이섬유 함량을 정량 하였다. 무기질함량은 inductively coupled plasma-atomic emission spectrophotometer (ICP-AES) 법을 이용하여 측정 하였다(13).

\section{아미노산 함량 측정}

아미노산을 측정하기 위하여 동결건조한 후 분쇄한 분말 을 사용하였고, 구성 아미노산 분석방법은 $\mathrm{AOAC}$ 법(18)에 준하여 수행하였다. 유리 아마노산 함량 측정을 위하여 백 년초와 천년초 열매의 분말 약 $1 \mathrm{~g}$ 을 $70 \%$ ethanol로 1 시간 동안 초음파 추출(Bransonic 5510E-DTH, Branson ultrasonics corporation, Danbury, CT, USA)한 후 다시 실온에서 24 시간 추출하였으며, $0.2 \mu \mathrm{m}$ 여과용 필터(Whatman, $\mathrm{GE}$ Healthcare Life Sciences Co., Buckinghamshire, UK)를 이용 하여 여과한 후 $\mathrm{HPLC}$ 용 시료로 사용하였다. 분석 장치는 Dionex Ultimate 3000(Thermo Fisher Scientific Co., Waltham, MA, USA)이며, UV Detector를 이용해 $338 \mathrm{~nm}$ 에서 분석하 였다.

\section{통계분석}

손바닥선인장 열매의 성분분석 결과에 대한 통계처리는 
IBM SPSS Statistics(Ver 22.0, IBM Corp., Armonk, NY, USA)를 이용하여 측정하였고, 유의성 검증을 위해 t-test 및 Duncan's multiple range test를 실시하였다.

\section{결과 및 고찰}

\section{백년초 열매와 천년초 열매의 외관특성}

백년초 열매와 천년초 열매의 외형적 특성을 측정하기 위하여 타원형의 축 중 가장 긴축을 장축으로, 가장 짧은 축을 단축으로 정해 크기를 측정하였다. 백년초 열매의 외 형은 단축이 2.1 3.7 cm 범위로 나타났으며, 장축이 3.1 5.5 $\mathrm{cm}$, 중량은 9.3 26.9 $\mathrm{g}$ 범위로 나타났다. 반면 천년초 열매 의 외형은 단축이 $1.5 \sim 2.8 \mathrm{~cm}$, 장축이 $2.5 \sim 5.1 \mathrm{~cm}$ 로 백년초 열매보다 장축과 단축의 길이가 대체로 짧았으며, 중량도 $3.2 \sim 11.9 \mathrm{~g}$ 로 백년초 열매(평균 $16.6 \mathrm{~g}$ )가 천년초 열매(평균 $8.3 \mathrm{~g}$ )에 비해 약 2배 정도 무거운 것으로 나타났다 (Table 1). 평균적으로 각 열매 시료의 단축 대비 장축의 비를 계산 해 보면 백년초 열매는 1.63 , 천년초 열매는 1.90 으로 천년 초 열매가 백년초 열매에 비해 크기가 작은 대신 좀 더 길쭉한 모양을 가지는 것을 확인하였다. 이는 Fig. 1 의 외관 사진으로도 쉽게 확인이 가능하며 백년초 열매와 천년초

Table 1. Morphological features of Opuntia spp. fruits

\begin{tabular}{crrrrrr}
\hline & \multicolumn{3}{c}{ O. ficus-indica $(\mathrm{n}=100)$} & \multicolumn{4}{c}{ O. humifusa $(\mathrm{n}=100)$} \\
\cline { 2 - 7 } & Max. & Mean & Min. & Max. & Mean & Min. \\
\hline Minor axis (cm) & 3.7 & $2.7^{\mathrm{a})}$ & 2.1 & 2.8 & $2.1^{\mathrm{b}}$ & 1.5 \\
Major axis (cm) & 5.5 & $4.4^{\mathrm{a}}$ & 3.1 & 5.1 & $4.0^{\mathrm{b}}$ & 2.5 \\
Weight $(\mathrm{g})$ & 26.9 & $16.6^{\mathrm{a}}$ & 9.3 & 11.9 & $8.3^{\mathrm{b}}$ & 3.2 \\
\hline
\end{tabular}

${ }^{1)}$ Different superscripts in the same row are significantly different at $p<0.05$ by Duncan's multiple range test.

(A)

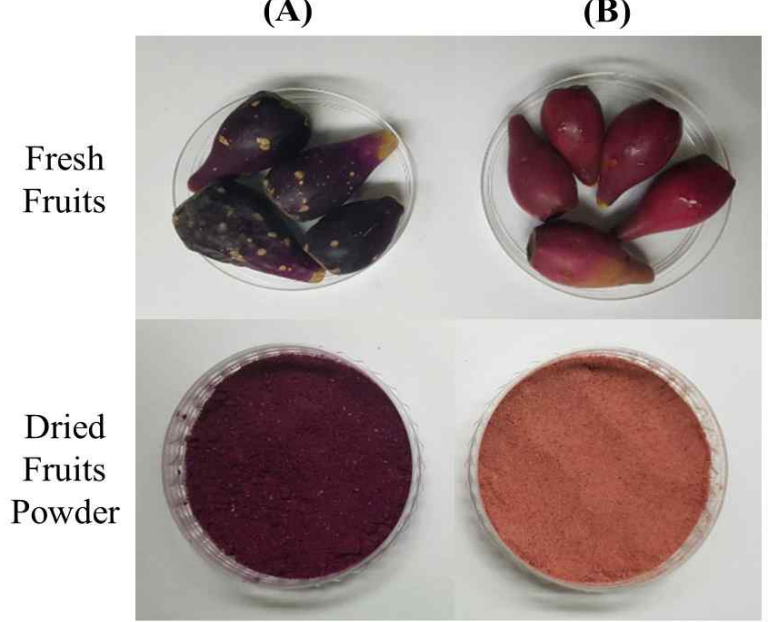

Fig. 1. The photos of Opuntia ficus-indica (A) and O. humifusa (B) fruits.
열매가 크기와 모양에 있어 상이한 점이 있다는 것을 확인 할 수 있었다. Fig. 2에서 백년초와 천년초 열매시료들의 크기 및 무게 분포를 살펴보면 각 시료들의 크기나 모양이 정규 분포에 가까운 형상을 보이는 것을 확인할 수 있었는 데 이는 열매의 경우 타원형의 형태를 가지고 있음에 기인 한다고 사료된다.

색 도

백년초와 천년초 열매 동결건조 분말의 색도를 측정한 결과는 Table 2에 나타내었다. 측정결과 L(lightness)값은 천년초 열매가 65.14로 백년초 열매 47.26보다 높게 나타났 으며, $\mathrm{b}$ (yellowness)값도 천년초 열매가 높은 값을 나타냈 다. 그러나 a(redness)값의 경우 백년초 열매에서 22.41로 천년초 열매 보다 높은 값을 나타냈다. Fig. 1에서 확인할 수 있듯이 백년초 열매분말의 경우 붉은색이 강한 좀 더 짙은 색깔을 나타내는데 비해 천년초 열매분말의 경우는 붉은색이 강하지 않은 밝은 색깔을 나타내었다. 백년초와 천년초 열매시료간의 색상차이를 나타내는 $\Delta \mathrm{E}$ 값은 19.80 으로 나타났다.

Table 2. Hunter's color values of Opuntia spp. fruits

\begin{tabular}{ccc}
\hline & O. ficus-indica (A) & O. humifusa (B) \\
\hline L (lightness) & $47.26 \pm 1.56^{1 \mathrm{~b} 22}$ & $65.14 \pm 1.21^{\mathrm{a}}$ \\
a (redness) & $22.41 \pm 0.65^{\mathrm{a}}$ & $16.86 \pm 0.53^{\mathrm{b}}$ \\
b (yellowness) & $-3.70 \pm 0.31^{\mathrm{b}}$ & $2.75 \pm 0.15^{\mathrm{a}}$ \\
$\Delta \mathrm{E}$ (color difference) & & 19.80 \\
\hline
\end{tabular}

${ }^{11}$ All results are expressed as mean \pm SD for three replicates.

${ }^{2)}$ Different superscripts in the same row are significantly different at $\mathrm{p}<0.05$ by Duncan's multiple range test.

3) $=\left(L-L_{B}\right)+\left(a_{A}-a_{B}\right)^{2}+\left(b_{A}-b_{B}\right)^{2}$

\section{일반성분 및 식이섬유 함량}

수확 후 건조를 하지 않은 생 시료의 총 수분함량은 천년 초 열매가 $86.75 \%$ 로 백년초 열매의 수분함량 보다 높은 값을 보였다(Table 3).

백년초와 천년초 열매의 동결건조 된 분말을 이용하여 일반성분을 분석한 결과는 Table 3 에 나타내었다. 동결건조 물의 수분 함량은 백년초 열매가 $1.99 \%$ 로 천년초 열매의 동결건조 수분함량 $(0.10 \%)$ 보다 높게 나타났으며, 탄수화 물 함량도 백년초 열매가 높은 것 $(86.58 \%)$ 을 확인 할 수 있었다. 그러나 조회분 함량은 천년초 열매가 $14.08 \%$ 로 백년초 열매의 조회분 함량 $(5.07 \%)$ 보다 높게 나타났다. 조단백질 함량과 조지방 함량은 백년초와 천년초 열매에서 유사하게 나타났다. 백년초와 천년초 열매의 일반성분은 이전 보고된 결과들(13-15)과 비교하여 수분함량이 낮은 것을 제외하고는 유사한 수치를 나타내었는데, 수분함량의 차이는 동결건조 조건의 차이에 기인한 것으로 사료된다. 백년초와 천년초 열매의 식이섬유 함량을 조사한 결과는 
Table 3. Chemical compositions of Opuntia spp. fruits

(unit: \%)

\begin{tabular}{cccc}
\hline & & O. ficus-indica & O. humifusa \\
\hline Fresh fruits & Total moisture & $80.46 \pm 0.88^{1 \mathrm{1b} 2 \mathrm{~b}}$ & $86.75 \pm 1.30^{\mathrm{a}}$ \\
\hline & Moisture & $1.99 \pm 0.08^{\mathrm{a}}$ & $0.10 \pm 0.05^{\mathrm{b}}$ \\
& Crude protein & $4.42 \pm 0.14$ & $4.44 \pm 0.03$ \\
Dried & Crude ash & $5.07 \pm 0.20^{\mathrm{b}}$ & $14.08 \pm 0.21^{\mathrm{a}}$ \\
fruits & $1.96 \pm 0.02$ & $1.98 \pm 0.01$ \\
powder & Crude fat & $86.58 \pm 0.02^{\mathrm{a}}$ & $79.36 \pm 0.28^{\mathrm{b}}$ \\
& Carbohydrate & $52.73 \pm 0.32$ & $53.39 \pm 1.00$ \\
\hline
\end{tabular}

${ }^{1)}$ All results are expressed as mean \pm SD for three replicates.

${ }^{2}$ Different superscripts in the same row are significantly different at $\mathrm{p}<0.05$ by Duncan's multiple range test.

\section{O. ficus-indica}
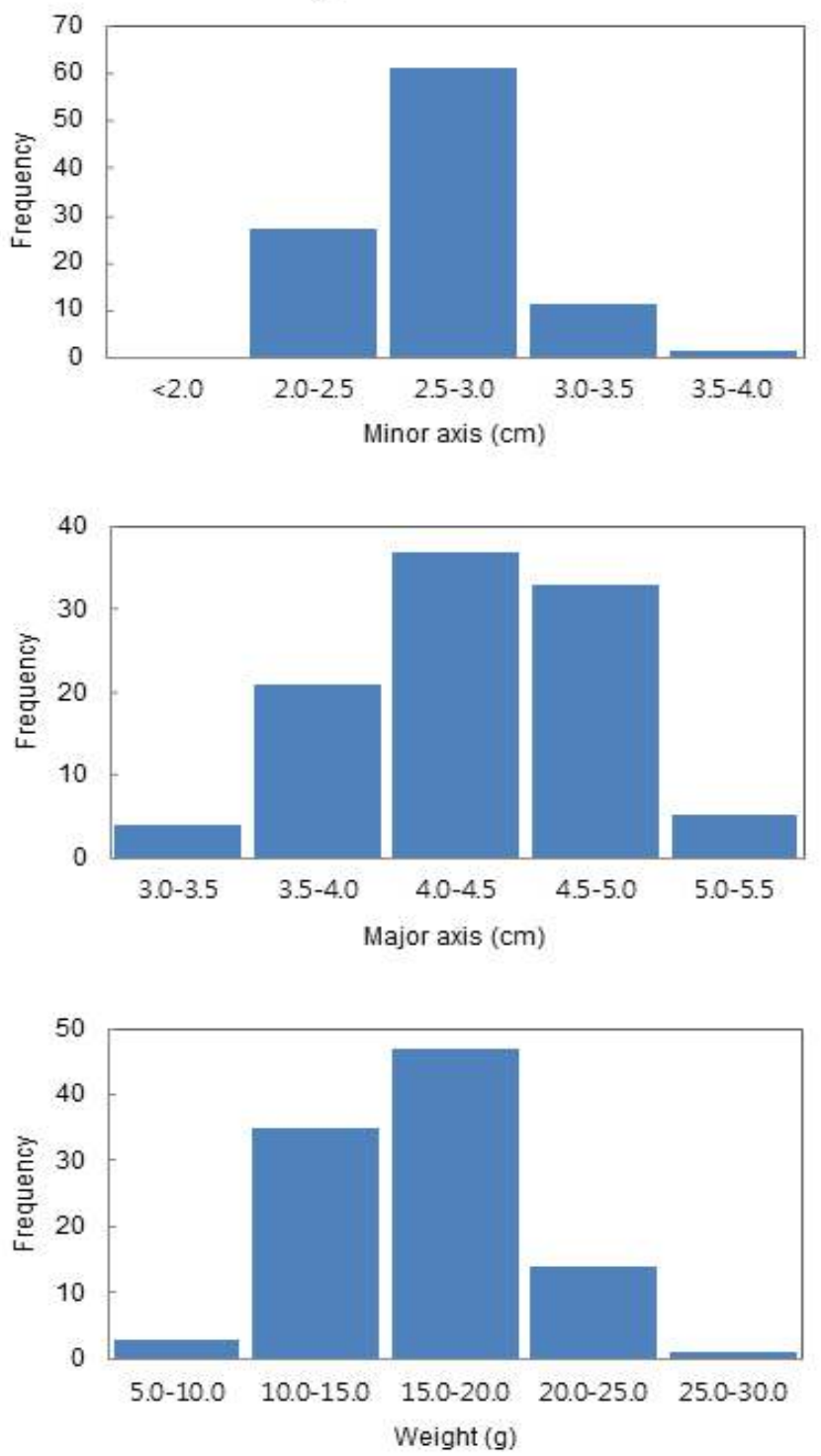

Table 3과 같다. 백년초와 천년초 열매 모두 유사한 수준으 로 높은 식이섬유 함량(52.7 53.4\%)을 가지고 있는 것으로 나타났다. 제주 백년초 선인장 열매의 식이석유함량을 보 고한 연구에서는, 백년초 열매의 식이섬유 함량을 $32.5 \%$ 로 보고하여 식이섬유함량이 높다고 알려진 알로에(31.0\%), 상용하는 곡류(1.19 10.35\%), 식품으로 상용하지 않는 쌀 겨, 밀기울의 식이섬유 함량(21.7 32.0\%)보다 높으며 해조 류(28.70 38.19\%)와 비슷한 수준으로 보고하였다(13). 식 이섬유란 인간의 소화관에서 분비되는 효소에 의해 소화되 지 않는 식물성 다당류와 리그닌의 합계치 라고 정의되어 왔으나, 최근에는 동물성 급원의 난소화성 다당류까지 포 함하고 있다. 식이섬유는 보수성이 좋고, 대변량의 증가나 장의 연동운동 촉진, 지방이나 담즙산, 발암 물질 등의 흡
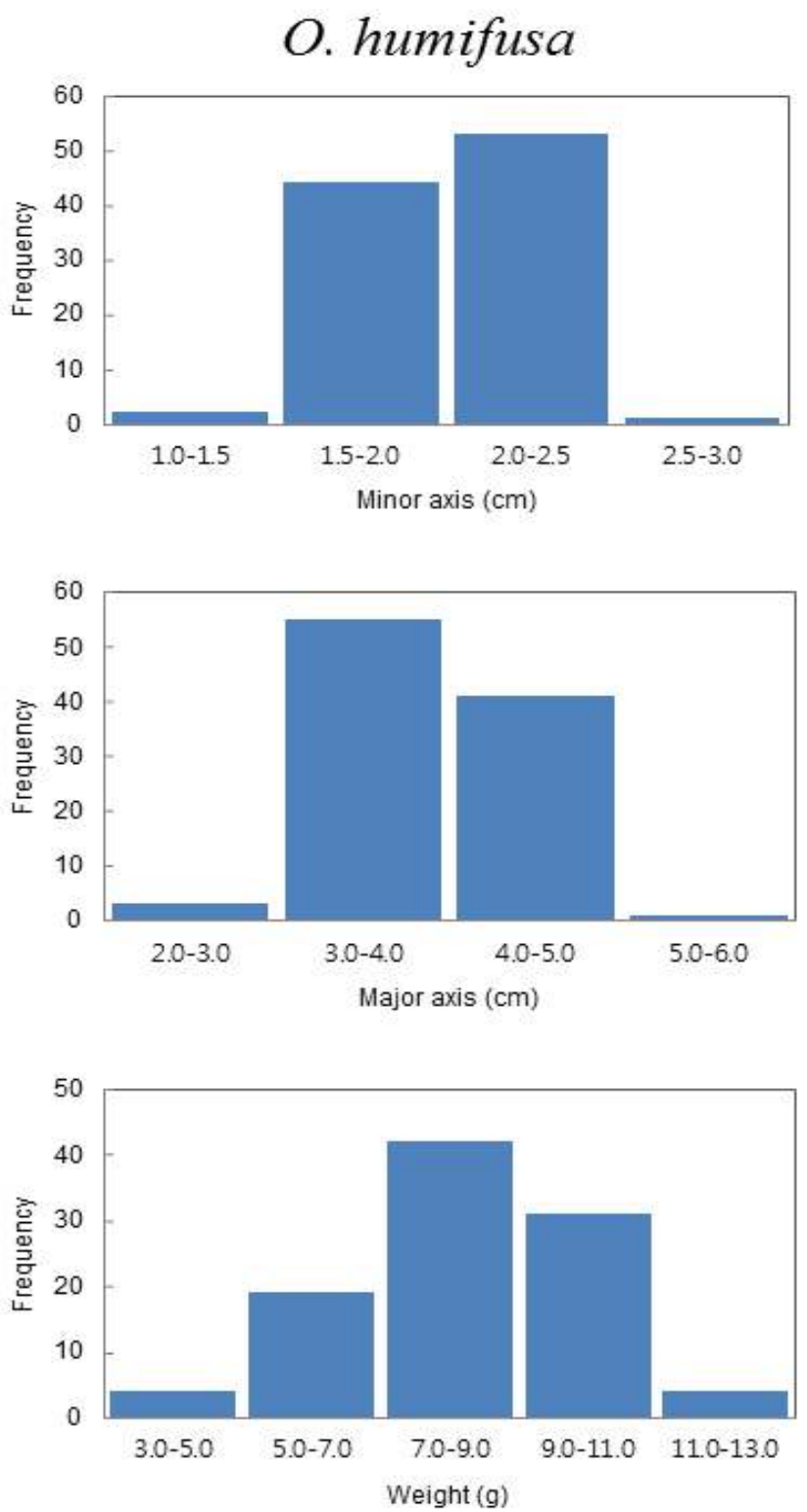

Fig. 2. Interval distribution of morphological features of Opuntia spp. fruits. 
착·배출 작용을 할 수 있는 기능성 소재(19)로, 백년초와 천년초 열매는 높은 식이섬유 함량을 가지고 있어 다이어트 용 기능성식품 개발 등에 이용될 수 있을 것으로 기대되어 진다.

\section{무기질 함량}

백년초와 천년초 열매의 무기질 함량으로 $\mathrm{Ca}, \mathrm{Fe}, \mathrm{K}, \mathrm{Mg}$, $\mathrm{Na}, \mathrm{P}$ 을 측정한 결과는 Table 4 와 같다. 백년초와 천년초 열매의 주요 무기질은 $\mathrm{K}$ (백년초: $1,255.28$, 천년초: $1,054.32$ $\mathrm{mg} \%$ )과 $\mathrm{Ca}$ (백년초: 791.90 , 천년초: $938.97 \mathrm{mg} \%$ )으로 이전 의 연구결과들과 일치하는 경향을 보였고(13-15), $\mathrm{Na}$ 의 함 량(백년초: 279.54 , 천년초: $3.94 \mathrm{mg} \%$ )을 제외하고는 백년 초와 천년초 열매가 비슷한 무기질 조성을 가지는 것을 확인할 수 있었다. 한국인이 주로 섭취하는 과일의 무기질 함량을 조사한 이전 연구에서 사과, 배, 귤, 딸기의 $\mathrm{K}$ 함량은 $74 \sim 303 \mathrm{mg} \%, \mathrm{Ca}$ 함량은 $1.70 \sim 12.68 \mathrm{mg} \%$ 로 보고되어(20), 백년초와 천년초 열매가 다른 과일들에 비해 $\mathrm{K}$ 과 $\mathrm{Ca}$ 의 함량이 높다는 것을 확인할 수 있었다. 특히 $\mathrm{Ca}$ 이 많이 함유되어 있다고 알려진 멸치의 $\mathrm{Ca}$ 함량이 $1,094 \mathrm{mg} \%$ 로 보고(21)된 것을 고려해 보았을 때 손바닥선인장 열매의 경우 주요한 $\mathrm{Ca}$ 공급원으로 사용될 수 있을 것으로 사료되 었다.

Table 4. Mineral contents of Opuntia spp. fruits

\begin{tabular}{ccc} 
& & (unit: $\mathrm{mg} \%)$ \\
\hline $\mathrm{Ca}$ & O. ficus-indica & O. humifusa \\
$\mathrm{Fe}$ & $191.90 \pm 58.05^{11 \mathrm{~b} 2)}$ & $938.97 \pm 18.46^{\mathrm{a}}$ \\
$\mathrm{K}$ & $1.32 \pm 0.03^{\mathrm{b}}$ & $2.33 \pm 0.02^{\mathrm{a}}$ \\
$\mathrm{Mg}$ & $1,255.28 \pm 63.05$ & $1,054.32 \pm 19.52$ \\
$\mathrm{Na}$ & $428.24 \pm 23.64^{\mathrm{a}}$ & $209.57 \pm 3.01^{\mathrm{b}}$ \\
$\mathrm{P}$ & $297.54 \pm 14.36^{\mathrm{a}}$ & $3.94 \pm 0.41^{\mathrm{b}}$ \\
\hline
\end{tabular}

${ }^{1)}$ All results are expressed as mean \pm SD for three replicates.

${ }^{2)}$ Different superscripts in the same row are significantly different at $p<0.05$ by Duncan's multiple range test.

\section{아미노산 함량}

백년초와 천년초 열매의 구성 아미노산 함량을 조사한 결과는 Table 5 와 같다. 전체 아미노산의 양은 천년초 열매 가 $3,828.04 \mathrm{mg} \%$ 로 백년초 열매 $(3,140.38 \mathrm{mg} \%)$ 에 비해 많 았으나 필수 아미노산의 비율은 백년초 열매가 $29.81 \%$ 로 천년초 열매(26.32\%)에 비해 소폭 높았다. 백년초와 천년초 열매의 구성 아미노산 조성은 전체적으로 유사한 수준을 나타내었다. 백년초와 천년초 열매의 구성 아미노산 중 가 장 많이 함유되어 있는 것은 glutamic acid로 천년초 열매는 $1,342.93 \mathrm{mg} \%$, 백년초 열매는 $733.51 \mathrm{mg} \%$ 로 총 구성 아미 노산 대비 각각 $23.36 \%, 42.76 \%$ 를 차지하였다. 이전 연구에
서도 glutamic acid의 백년초 열매 함량은 $605.7 \mathrm{mg} \%(13)$, 천년초 열매 함량은 $706.76 \mathrm{mg} \%$ (15)로 구성 아미노산 중 가장 높은 함량을 가지는 것으로 보고되어 본 연구와 유사 한 경향을 보였다, 이를 바탕으로 손바닥선인장 열매의 대 표 아미노산은 glutamic acid인 것으로 사료되었다.

Table 5. Total amino acids of Opuntia spp. fruits

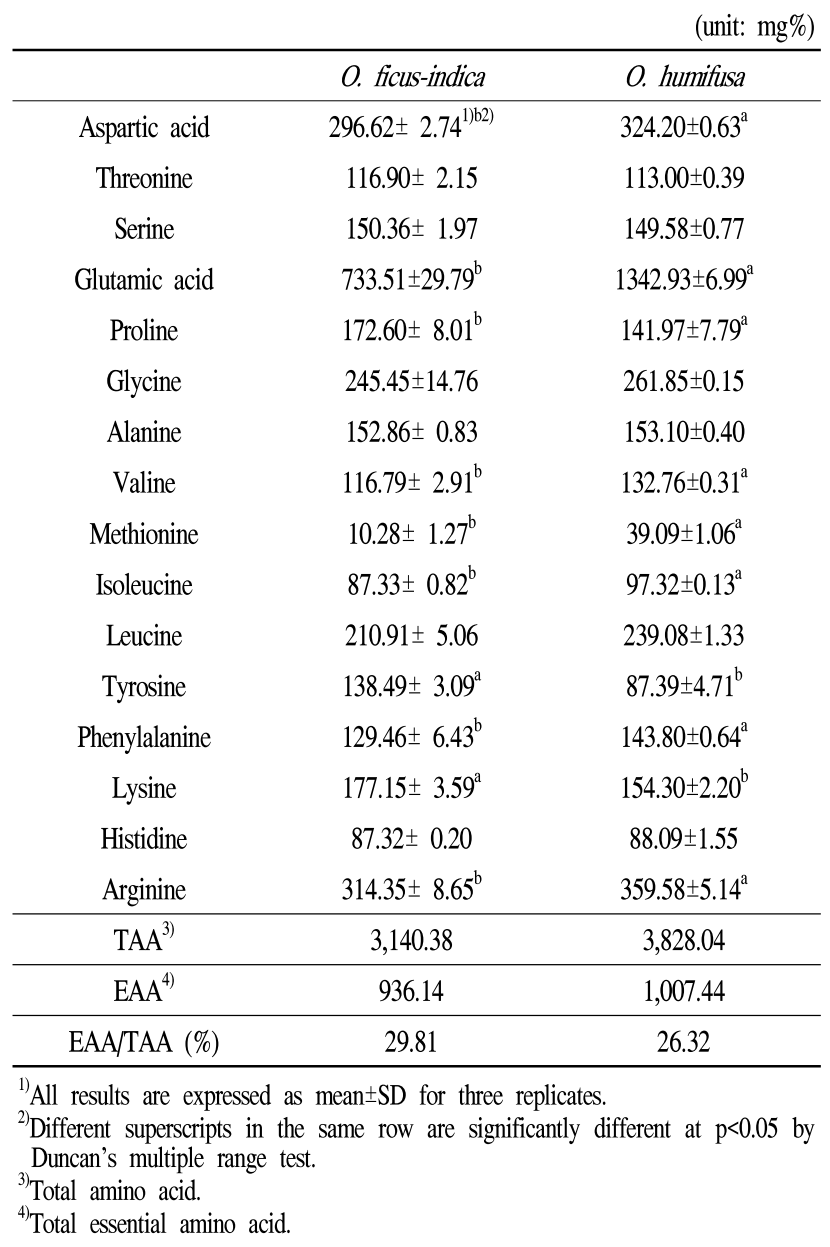

백년초와 천년초 열매의 유리 아미노산 함량을 조사한 결과는 Table 6과 같다. 유리된 아미노산의 경우 시료별 특성이 달랐는데, 백년초 열매의 경우 tyrosine의 함량이 높고 천년초 열매에 존재하지 않는 taurine이 존재한 반면, 천년초 열매의 경우 glutamic acid의 함량이 $653 \mathrm{mg} \%$ 로 압도적으로 높은 것을 확인할 수 있었다(총 유리아미노산 대비 $81.8 \%$ ). 특이한 점은 손바닥선인장 열매들이 $\mathrm{r}$ -aminobutyric acid(GABA)를 함유하고 있다는 것이었다. $\mathrm{GABA}$ 는 자연계에 분포하는 비단백태 아미노산의 일종으 로 인체 내에서는 뇌와 척수에 존재하는 신경전달물질로 혈압 강하, 비만 방지 효과 외에 뇌의 혈류 개선 및 신경안정 효과 등의 생리활성이 보고되어 건강기능성 식품소재로 관심을 끌고 있으며, 일본에서는 $\mathrm{GABA}$ 를 첨가한 가공식품 
과 음료 등이 판매되고 있다(22). GABA는 현미 2 6 $\mathrm{mg} \%$, 발아현미 10 13.5 mg\%, 품종별 발아보리 $14.3 \sim 20.9 \mathrm{mg} \%$ 등 발아된 곡류에 많이 함유되어 있다고 보고된 바 있는데(23), 백년초와 천년초 열매는 각각 $25.99 \mathrm{mg} \%$ 와 $10.71 \mathrm{mg} \%$ 의 $\mathrm{GABA}$ 함량을 가지고 있어 발아된 곡류와 유사한 $\mathrm{GABA}$ 함 량을 나타내었다.

Table 6. Free amino acids of Opuntia spp. fruits

\begin{tabular}{|c|c|c|}
\hline & O. ficus-indica & O. humifusa \\
\hline Aspartic acid & $24.01 \pm 0.28^{1 / 22)}$ & $31.68 \pm 2.78^{b}$ \\
\hline Glutamic acid & $71.21 \pm 0.62^{b}$ & $653.00 \pm 58.81^{\mathrm{a}}$ \\
\hline Asparagine & $6.63 \pm 0.11^{\mathrm{a}}$ & $2.05 \pm 0.18^{b}$ \\
\hline Serine & $22.49 \pm 0.11^{\mathrm{a}}$ & $15.58 \pm 1.23^{b}$ \\
\hline Glutamine & $31.16 \pm 0.04^{\mathrm{a}}$ & $8.83 \pm 0.54^{b}$ \\
\hline Histidine & $5.30 \pm 0.15^{\mathrm{a}}$ & $1.50 \pm 0.26^{b}$ \\
\hline Glycine & $6.19 \pm 0.05^{\mathrm{a}}$ & $0.98 \pm 0.03^{b}$ \\
\hline Threonine & $4.63 \pm 0.10^{\mathrm{a}}$ & $2.20 \pm 0.26^{b}$ \\
\hline Arginine & $36.05 \pm 0.23^{\mathrm{a}}$ & $2.31 \pm 0.11^{b}$ \\
\hline Alanine & $12.97 \pm 0.13^{\mathrm{a}}$ & $6.98 \pm 0.40^{b}$ \\
\hline Taurine & $15.32 \pm 0.04$ & - \\
\hline$\gamma$-aminobutyric acid & $25.99 \pm 0.00^{\mathrm{a}}$ & $10.71 \pm 0.93^{b}$ \\
\hline Tyrosine & $179.50 \pm 0.05^{\mathrm{a}}$ & $1.19 \pm 0.30^{b}$ \\
\hline Valine & $9.72 \pm 0.19^{\mathrm{a}}$ & $8.07 \pm 0.17^{b}$ \\
\hline Methionine & $5.35 \pm 0.13^{\mathrm{a}}$ & $0.83 \pm 0.09^{b}$ \\
\hline Tryptophane & $18.23 \pm 0.22^{\mathrm{a}}$ & $4.11 \pm 0.24^{b}$ \\
\hline Phenylalanine & $14.91 \pm 0.08^{\mathrm{a}}$ & $1.99 \pm 0.01^{b}$ \\
\hline Isoleucine & $9.10 \pm 0.08$ & $8.01 \pm 0.40$ \\
\hline Leucine & $10.46 \pm 0.07^{\mathrm{a}}$ & $2.66 \pm 0.26^{b}$ \\
\hline Lysine & $6.38 \pm 2.27^{b}$ & $1.07 \pm 0.05^{b}$ \\
\hline Proline & $79.58 \pm 3.04^{\mathrm{a}}$ & $34.17 \pm 1.88^{\mathrm{b}}$ \\
\hline $\mathrm{TAA}^{3)}$ & 595.18 & 797.92 \\
\hline $\mathrm{EAA}^{4)}$ & 78.78 & 28.94 \\
\hline $\mathrm{EAA} / \mathrm{TAA}(\%)$ & 13.24 & 3.63 \\
\hline
\end{tabular}

${ }^{10}$ All results are expressed as mean $\pm \mathrm{SD}$ for three replicates.

${ }^{2)}$ Different superscripts in the same row are significantly different at $\mathrm{p}<0.05$ by Duncan's multiple range test.

${ }^{3)}$ Total amino acid.

${ }^{4)}$ Total essential amino acid.

\section{요 약}

본 연구에서는 우리나라에서 재배되고 있는 손바닥선인 장인 백년초(Opuntia ficus-indica var. saboten)와 천년초 (Opuntia humifusa) 열매의 외관 및 성분을 비교하였다. 시 료 간 외형을 장축, 단축, 중량의 항목으로 구분하여 측정,
비교하였으며, 색도를 측정하여 외관을 비교하였다. 크기 와 무게는 천년초 열매가 백년초 열매에 비해 작았으나, 단축 대비 장축의 비가 백년초 열매는 1.63 , 천년초 열매는 1.90 으로 천년초 열매가 백년초 열매에 비해 크기가 작은 대신 좀 더 길쭉한 모양을 가지는 것을 확인하였다. 색도의 경우 $\mathrm{L}$ 값과 $\mathrm{b}$ 값은 천년초 열매가, $\mathrm{a}$ 값은 백년초 열매가 높았는데, 열매시료간의 $\Delta \mathrm{E}$ 값은 19.80 으로 나타나 색도 차 이가 크게 나타나는 것으로 나타났다. 일반성분의 함량은 백년초 열매가 탄수화물 함량이 높은 반면 조회분 함량은 천년초 열매가 높게 나타났으며, 조단백질 함량과 조지방 함량은 유사하게 나타났다. 식이섬유 함량은 백년초와 천 년초 열매 모두 유사한 수준으로 높은 함량(52.7 53.4\%)을 가지고 있는 것으로 나타났는데, 식이섬유 함량이 높다고 알려진 알로에와 해조류보다도 높은 수준으로 나타났다. 무기질 함량은 두 시료에서 $\mathrm{K}$ 과 $\mathrm{Ca}$ 순으로 높게 나타났는 데, 한국인이 주로 섭취하는 과일의 $\mathrm{K}$ 과 $\mathrm{Ca}$ 함량에 비해 높은 함유량을 나타내었고, $\mathrm{Ca}$ 이 많이 함유되어 있다고 보고된 멸치와 비슷한 $\mathrm{Ca}$ 함량을 나타내었다. 구성아미노 산의 함량은 전체 합이 천년초 열매가 백년초 열매에 비해 높았으나 필수 아미노산의 비율은 백년초 열매가 천년초 열매에 비해 소폭 높았고, 모든 시료에서 glutamic acid의 함량이 가장 높은 특징을 보였다. 유리 아미노산의 경우 시료별 특성이 달랐는데, 백년초 열매의 경우 tyrosine의 함량이 높고 천년초 열매에 존재하지 않는 taurine이 존재한 반면, 천년초 열매의 경우 glutamic acid의 함량이 압도적으 로 높은 것을 확인할 수 있었으며, 모든 시료에서 GABA가 검출되었다. 본 연구결과 백년초와 천년초 열매가 외관특 성 및 성분에 차이를 보이는 것을 확인할 수 있었는데, 손바 닥선인장 열매의 가공제품 개발 시 종에 따른 외관과 성분 함량 차이를 고려할 필요가 있을 것으로 판단되었고 특히 손바닥선인장 열매의 경우 식이섬유와 $\mathrm{Ca}$ 의 함량의 높아 이를 이용한 기능성식품의 제조에 이용될 수 있을 것으로 사료되었다.

\section{감사의 글}

본 연구는 농림축산식품부 고부가가치 식품기술개발사 업에 의해 이루어진 것으로 연구비 지원에 감사드립니다.

\section{References}

1. Park CM, Kwak BH, Park SH, Kim H, Rhyu DY (2013) Comparison of biological activities of Opuntia humifusa and Opuntia ficus-indica. Korean J Plant Res, 26, 519-525 2. Lee YC, Pyo YH, Ahn CK, Kim SH (2005) Food 
functionality of Opuntia ficus-indica var. cultivated in Jeju island. J Food Sci Nutr, 10, 103-116

3. Jang SY, Kim MH, Hong GJ (2012) Quality characteristics of Sulgidduk added with Cheonnyuncho fruit powder. J East Asian Soc Dietary Life, 22, 365-373

4. Saenz C (2000) Processing technologies: an alternative for cactus pear (Opuntia spp.) fruits and cladodes. J Arid Environ, 46, 209-225

5. Jeon ER, Park ID (2006) Effect of Angelica plant powder on the quality characteristics of batter cakes and cookies. Korean J Food Cookery Sci, 22, 62-68

6. Joubert E (1993) Processing of the fruit of five prickly pear cultivars grown in South Africa. International J Food Sci Technol, 28, 377-387

7. Kim NY, Cho AR, Jung SJ, Kim KH, Lee HJ, Lee S, Yook HS (2007) Quality characteristics of cupcakes added with Opuntia ficus-indica var. saboten powder. J Korean Soc Food Sci Nutr, 36, 58-64

8. Song JH, Park JS, No YJ, Choi HJ (2011) A study on the quality characteristics of soybean curd prepared with the addition of Opuntia humifusa fruit. Korean J Food Nutr, 24, 12-16

9. Kim MJ (2008) Physicochemical characteristics of Jeung-pyun by different addition ratios of prickly pear powder during storage. MS Thesis, Sungshin Women's University, Korea, p 1

10. Jung BM, Kim DS, Joo NM (2013) Quality characteristics and optimization of cookies prepared with Opuntia humifusa powder using response surface methodology. Korean J Food Cookery Sci, 29, 1-10

11. Kim MH, Hong GJ (2009) Quality properties of Jeolpyun supplemented with Cheonnyuncho (Opuntia humifusa). Korean J Food Cookery Sci, 25, 415-420

12. Cho EJ, Kim MJ, Choi WS (2007) Quality properties of Jeung-pyun with added with prickly pear (Cheonnyuncho) powder. J East Asian Soc Dietary Life, 17, 903-910

13. Lee YC, Hwang KH, Han DH, Kim SD (1997) Compositions of Opuntia ficus-indica. Korean J Food Sci Technol, 29, 847-853
14. Jung BM, Han KA, Shin TS (2011) Food components of different parts of Cheonnyuncho (Opuntia humifusa) harvested from Yeosu, Jeonnam in Korea. J Korean Soc Food Sci Nutr, 40, 1271-1278

15. Shin DS, Han GJ (2016) Chemical compositions and antioxidant activities of Cheonnuncho (Opuntial hunifusa) stems and fruit. Korean J Food Preserv, 23, 89-96

16. Saenz C (2013) Chemical composition and characteristics of Opuntia spp.. In: Agro-industrial utilization of cactus pear, Saenz (Editor), FAO, Rome, Italy, p 9

17. Oliveira ACM, Balaban MO (2006) Comparison of a colorimeter with a machine vision system in measuring color of gulf of mexico sturgeon fillets. Appl Eng Agric, 22, 583-587

18. AOAC (1996) Official Methods of Analysis. 15th ed, The Association of Official Analytical Chemistry, Washington DC, USA

19. Rodriguez R, Jimenez A, Fernandez-Bolanos J, Guillen R, Heredia A (2006) Dietary fibre from vegetable products as source of functional ingredients. Trends Food Sci Tech, 17, 3-15

20. Kim JH, Kim MJ, Oh HK, Chang MJ, Kim SH (2007) Seasonal variation of mineral nutrients in Korean common fruits and vegetables. J East Asian Soc Dietary Life, 17, 860-875

21. Kim IS, Lee TG, Yeum DM, Cho ML, Park HW, Cho TJ, Heu MS, Kim JS (2000) Food component characteristics of cold air dried anchovies. J Korean Soc Food Sci Nutr, 29, 973-980

22. Jung HW, Chung HJ (2013) Quality characteristics and amino acid content of cookies with GABA-enhanced brown rice. J Korean Soc Food Sci Nutr, 42, 1813-1820

23. Na HS, Kim JY, Park HJ, Choi GC, Yang SI, Lee JH (2013) Comparison of the nutrient components of figs based on their cultivars. Korean J Food Preserv, 20, 336-341 